ity and imagination, not with reflexive and heavy-handed strategies. Einstein once said, "Imagination is more important than knowledge." ${ }^{\prime}$ Until we dare to imagine the real causes of this multifaceted problem, until we stop racing for a quick fix and instead tune in to the personal unhappiness, the profound dissatisfaction with life, that lies at its root, then we are doomed to go on seeing the problem as a mathematical equation in which the variables are caloric intake and expenditure.

I can't think of a better way to damage the self-esteem of children than to tell them, tactfully or otherwise, that their bodies are overfed or underexercised. By adding the official voice of family physicians and pediatricians to the consumerist messages already bombarding them about diet and exercise, we will be endorsing the exploitative purveyors of these messages. We will be telling our kids that they are not okay, and we will drive many of them into the waiting arms of anorexia and bulimia.

Theologian and historian Matthew Fox has characterized our society as one that "devours its youth." "This is a strange cultural pathology indeed.

Joan Johnston is a family physician in Edmonton, Alta.

\section{References}

1. The Eating Disorder Education Organization, www.edeo.org (accessed 2004 Nov 15).

2. Ratnasuryi RH, Eisler I, Szmukler GI, Russell GFM. Anorexia nervosa: outcome and prognostic facts. Br 7 Psych 1991;158:495-502.

3. Desroches L. Allow the water. Toronto: Dunamis Publishers; 1996. p. 172.

4. Fox M. The coming of the cosmic Christ. San Francisco: HarperCollins; 1988. p. 181.

\title{
A survey of entertainment extremes among medical students in Croatia
}

\author{
Svjetlana Dolovčak, Davorka Dušek, Darko Hren, Ana Marušić, Matko Marušić
}

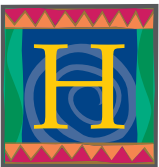

ow do medical students spend their free time? Are they overindulging in any sort of entertainment? Are there any predictors of the entertainment choices they make? An anonymous, voluntary questionnaire survey of medical students in Zagreb, Croatia, yielded some important results. It seems that appreciation for a drunken state and lower inner motivation will take students to a disco club, whereas the perception of having little free time will keep them at home, especially if they are male. Students who choose going to the theatre as the only sort of fun to have seem to be nonsmokers and nondrinkers, who have just enough free time ...

All authors are from the Zagreb University School of Medicine, Zagreb, Croatia. Svjetlana Dolovčak and D. Dušek are fifth-year students of the Zagreb University School of Medicine.

\begin{tabular}{|c|c|c|}
\hline \multicolumn{3}{|c|}{ Predictors of students' extreme choices of entertainment in their free time } \\
\hline $\begin{array}{l}\text { Extreme choice } \\
(N=687)\end{array}$ & Predictors for extreme choice & Odds ratio $(95 \% \mathrm{Cl})$ \\
\hline \multirow{3}{*}{$\begin{array}{l}\text { Stay home all the time } \\
(n=47) \text { (see Fig. A) }\end{array}$} & Male sex & $2.11(1.02-4.35)$ \\
\hline & Perception of having less free time & $1.43(1.10-2.01)$ \\
\hline & Gets drunk less often & $2.68(1.40-5.13)$ \\
\hline \multirow{3}{*}{$\begin{array}{l}\text { Go to disco club only, } \\
>20 \text { times/yr }(n=75) \\
\text { (see Fig. B) }\end{array}$} & Gets drunk more often & $2.45(1.59-3.78)$ \\
\hline & Lower inner motivation & $1.10(1.05-1.16)$ \\
\hline & Lower GPA & $1.14(1.04-2.47)$ \\
\hline \multirow{4}{*}{$\begin{array}{l}\text { Attend theatre only } \\
(n=50) \text { (see Fig. C) }\end{array}$} & Has not failed a year & $2.26(1.13-4.52)$ \\
\hline & Perception of having more free time & $1.53(1.10-2.15)$ \\
\hline & Gets drunk less often & $3.04(1.56-5.95)$ \\
\hline & Does not smoke & $3.40(1.11-11.76)$ \\
\hline
\end{tabular}

Note: $\mathrm{Cl}=$ confidence interval, GPA = grade point average.
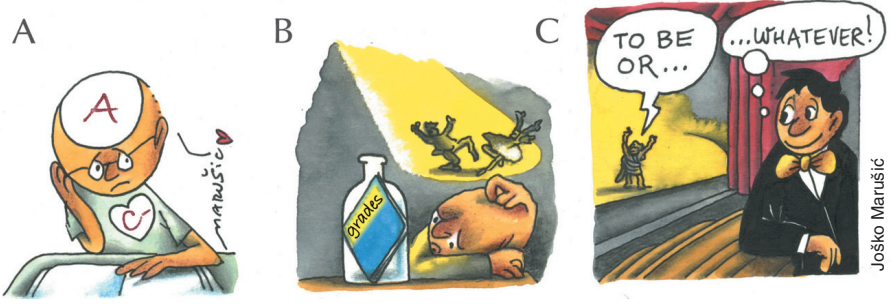